\title{
Clinical and Nonclinical Disposition and In Vitro Drug-Drug Interaction Potential of Felcisetrag, a Highly Selective and Potent 5- $\mathrm{HT}_{4}$ Receptor Agonist
}

\author{
Sandeepraj Pusalkar ${ }^{1,2} \cdot$ Swapan K. Chowdhury ${ }^{1,3} \cdot$ Richard Czerniak $^{1} \cdot$ Xiaochun Zhu $^{1} \cdot$ Yuexian $i^{1}$. \\ Suresh K. Balani ${ }^{1}$ - Diane Ramsden ${ }^{1,4}(\mathbb{D}$
}

Accepted: 12 December 2021 / Published online: 14 February 2022

(c) The Author(s) 2022

\begin{abstract}
Background and Objective Felcisetrag (previously TAK-954 or TD-8954) is a highly selective and potent 5-HT receptor $^{2}$ agonist in clinical development for prophylaxis and treatment of postoperative gastrointestinal dysfunction (POGD). The rat, dog, and human absorption, distribution, metabolism, and excretion (ADME) properties of felcisetrag were investigated. Methods The metabolism and victim and perpetrator drug interaction potentials towards cytochrome P450s (CYP) and transporters were determined using in vitro models. The excretion, metabolite profile, and pharmacokinetics were determined during unlabeled and radiolabeled ADME studies in rat and dog for comparison with human. Due to a low clinical dose $(0.5 \mathrm{mg})$ and radioactivity $(\sim 1.5 \mu \mathrm{Ci})$, a combination of liquid scintillation counting and accelerator mass spectrometry was used for analysis of samples in this study.

Results The ADME properties, including metabolite profile, for felcisetrag are generally conserved across species. Felcisetrag is primarily cleared through renal excretion $(0.443)$ and metabolism in humans $(0.420)$, with intact parent as the predominant species in circulation. There are multiple metabolites, each representing $<10 \%$ of the circulating radioactivity, confirming no metabolites in safety testing (MIST) liabilities. Metabolites were also detected in animals. The potential for major CYP- and transporter-based drug-drug interaction (DDI) of felcisetrag as a victim or perpetrator is considered to be low.

Conclusions Felcisetrag is primarily cleared in humans through renal excretion. Although the metabolism of felcisetrag is primarily through CYP3A, the potential for clinically relevant DDI as a victim is significantly reduced as metabolism plays a minor role in the overall clearance.
\end{abstract}

Diane Ramsden

diane.ramsden@astrazeneca.com

1 Present Address: Global; Drug Metabolism and Pharmacokinetics, Takeda Development Center Americas, Inc., 35 Landsdowne Street, Cambridge, MA 02139, USA

2 Present Address: Servier Pharmaceuticals, Cambridge, MA, USA

3 Present Address: Boston Pharmaceuticals, Cambridge, MA, USA

4 Present Address: AstraZeneca, Waltham, MA, USA 


\section{Graphical Abstract}

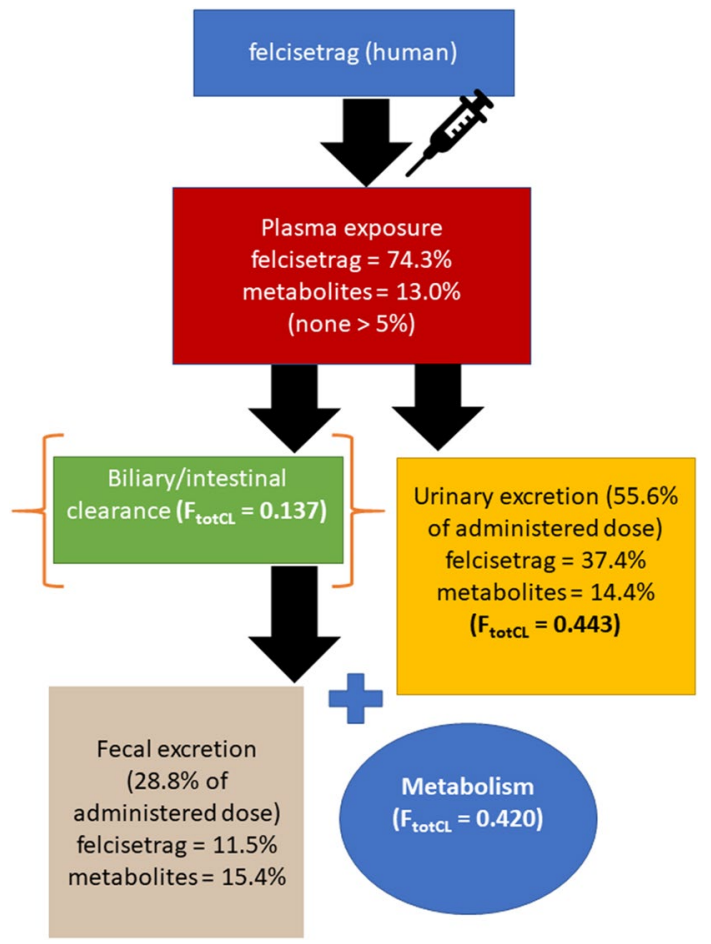

\section{Key Points}

The distribution, metabolism and excretion, and DDI potential of felcisetrag have been thoroughly investigated during in vitro and in vivo studies in rat, dog, and human.

Following IV administration to human, felcisetrag was the major circulating material and the minor metabolites formed were consistent with those formed in dog and rat.

The overall elimination of felcisetrag in human was primarily renal (0.443) followed by metabolic (0.420), and biliary or intestinal secretion (0.137).

The likelihood of DDI either as a victim or perpetrator is low.

\section{Introduction}

It is estimated that $17 \%$ of patients undergoing major abdominal surgery experience a temporary, nonobstructive impairment of upper and lower gastrointestinal (GI) motility (function), a condition commonly known as postoperative ileus (POI) or postoperative gastrointestinal dysfunction
(POGD), which can be associated with a prolonged length of stay (LOS) in the hospital [1,2]. Recent data suggest that upregulation of inflammatory pathways during surgery are a major factor in the development of POI and its duration [3], and that $5-\mathrm{HT}_{4}$ activation will decrease this effect resulting in shortened recovery of GI motility dysfunction $[4,5]$.

Felcisetrag, a highly selective and potent $5-\mathrm{HT}_{4}$ receptor agonist, is being developed as an intravenous (IV) therapy for prophylaxis and treatment of POGD. The in vivo potency and efficacy of felcisetrag have been demonstrated in nonclinical pharmacology studies [6, 7]. Felcisetrag has been investigated in Phase 1 studies in healthy subjects [8]. Characterization of felcisetrag in humans can help build an understanding of how the pharmacokinetics may change due to patient-specific factors, including renal and hepatic impairment or co-administration of other medications (drug-drug interactions). To elucidate the drug disposition in humans and any associated clinical implications, such as the potential for drug-drug interactions due to circulating metabolites, the mass balance, single-dose pharmacokinetics, metabolic pathways, and elimination profile of radiolabeled felcisetrag in healthy adult males were investigated as part of an open-label phase 1 trial following IV administration of $0.5 \mathrm{mg}$ felcisetrag containing a microtracer of $\sim 1.5$ $\mu \mathrm{Ci}\left[{ }^{14} \mathrm{C}\right]$ felcisetrag and compared with data from nonclinical investigations. 


\section{Materials and Methods}

\subsection{Chemicals and Reagents}

Felcisetrag, $\left[{ }^{14} \mathrm{C}\right]$ felcisetrag, THRX-204466 (M1), THRX746560 (M3), THRX-513466 (M10), and THRX-913682 (M5) were manufactured by Takeda or Theravance. All other reagents were of analytical grade. Substrates, inhibitors, stable isotope-labeled internal standards, and organic solvents were all obtained from commercial sources.

\subsection{In Vitro Metabolism of $\left[{ }^{14} \mathrm{C}\right]$ felcisetrag in Hepatocytes from Nonclinical Species and Human}

Suspended hepatocytes were prepared at $3.0 \times 10^{5}$ viable cells/well, and $\left[{ }^{14} \mathrm{C}\right]$ felcisetrag $(5 \mu \mathrm{M})$ was incubated for designated timepoints. Aliquots were removed for measurement of the radioactivity by LSC and metabolite profiling by HPLC analysis, as described in subsequent sections.

\section{Rat}

\subsection{Plasma Pharmacokinetics}

Three fed male Sprague Dawley rats, weighing between 342.4 and $371.4 \mathrm{~g}$ and 8 weeks of age at the time of dosing, were utilized. The dosing formulation was injected into the femoral veins of the rats at a single dose of $0.5 \mathrm{mg}-2.27$ $\mathrm{MBq} / 1.04 \mathrm{~mL} / \mathrm{kg}$ under anesthesia with isoflurane by inhalation. After intravenous (IV) administration of $\left[{ }^{14} \mathrm{C}\right]$ felcisetrag, $300 \mu \mathrm{L}$ of the blood was collected from the rat's tail vein with a heparinized glass capillary tube at $0.083,0.167$, $0.25,0.5,1,2,4,8$, and $24 \mathrm{~h}$, plasma was prepared, and radioactivity was determined by liquid scintillation counting (LSC).

\subsection{Rat ADME and Excretion in Intact and Bile Duct Cannulated Animals}

To evaluate the excretion pattern of felcisetrag in intact rats, 3 fed male Sprague Dawley rats, weighing between 330.8 and $342.4 \mathrm{~g}$ at 8 weeks of age, were administered a single IV dose of $\left[{ }^{14} \mathrm{C}\right]$ felcisetrag, $0.5 \mathrm{mg}-2.27 \mathrm{MBq} / 1.04 \mathrm{~mL} / \mathrm{kg}$. Following IV administration, the rats were housed in metabolic cages and samples were collected according to the following intervals: urine, $0-4,4-8,8-24$, and $24 \mathrm{~h}$ up to $168 \mathrm{~h}$; feces, 24-h up to $168 \mathrm{~h}$; and expired air (intact animals only). For biliary excretion, 4 bile duct cannulated Sprague Dawley rats, weighing between 274.4 and $287.3 \mathrm{~g}$ at 8 weeks of age, were administered a single IV dose of $\left[{ }^{14} \mathrm{C}\right]$ felcisetrag, 0.5 mg-2.27 MBq/1.04 mL/kg. Following IV administration, the rats were housed in metabolic cages and samples were collected according to the following intervals: bile and urine were collected at $0-4,4-8$ and 8-24 h, and feces were collected at $0-24 \mathrm{~h}$. Bile was collected in an amber glass bottle under dry ice-chilled conditions. Following sample collection, the rats were euthanized by exsanguination under anesthesia, gastric and intestinal contents were collected, and the carcasses was dissolved for measurement of radioactivity.

\subsection{Measurement of Radioactivity}

The radioactivity in the diluted dosing formulation, samples for HPLC, plasma, urine, $\mathrm{CO}_{2}$-absorbent solution with the expired air, and HPLC eluate were measured by LSC. The samples were mixed with $10 \mathrm{~mL}$ of liquid scintillator (Hionic-Fluor ${ }^{\mathrm{TM}}$; Perkin Elmer). To prepare samples for feces and whole blood analysis, they were transferred into combustion cones and dried in a drying oven at approximately $70{ }^{\circ} \mathrm{C}$ for $2 \mathrm{~h}$ or more and combusted in a sample oxidizer. In HPLC, the radioactivity was detected with a flow scintillation analyzer to which the liquid scintillator (UltimaFlo APTM; Perkin Elmer) was supplied at a flow rate of 3 $\mathrm{mL} / \mathrm{min}$. The radioactivity in each sample was calculated by subtracting the background value (cpm). The excretion ratio of radioactivity to the dose (\%) was calculated as described in Supplemental Methods.

\section{Dog ADME}

Four fed male beagle dogs, weighing between 11.8 to 12.4 $\mathrm{kg}$ and 22 months of age, were utilized to determine the plasma pharmacokinetics and excretion profiles of $\left[{ }^{14} \mathrm{C}\right]$ felcisetrag. The dosing formulation was injected into the cephalic veins of the left foreleg of the dogs at a single bolus dose of $0.5 \mathrm{mg}-0.731 \mathrm{MBq} / 0.2 \mathrm{~mL} / \mathrm{kg}$. Blood samples $(\sim 4$ $\mathrm{mL}$ ) were collected at $0.083,0.167,0.25,0.5,1,2,4,8,24$ and $48 \mathrm{~h}$ after injection, and urine and feces were collected at 24-h intervals up to $240 \mathrm{~h}$. Additional sample treatment was as described in the rat ADME section above, as were the methods for the measurement of radioactivity.

\section{Human ADME}

\subsection{Subjects}

The study was conducted at PRA Health Sciences in Groningen, Netherlands. Six healthy adult male volunteers were enrolled in the study, following informed consent. Their demographics were as follows: 5 White, and one Asian; 
median age 39 years (range 25-55); median weight and body mass index $78 \mathrm{~kg}$ (range 63.3-85.3), and $24.2 \mathrm{~kg} / \mathrm{m}^{2}$ (range $22-27 \mathrm{~kg} / \mathrm{m}^{2}$ ), respectively.

\subsection{Study Design, Objectives and Treatment}

The radiolabeled human mass balance study was designed to characterize the overall disposition and biotransformation of felcisetrag following a single 60-min IV infusion of 0.5 mg felcisetrag containing a microtracer of $\left[{ }^{14} \mathrm{C}\right]$ felcisetrag $(\sim 1.5 \mu \mathrm{Ci})$. Subjects were fasted for at least $2 \mathrm{~h}$ prior to drug administration and were confined from admission (Day - 1) for a minimum of 7 days to a maximum of 15 days ( $336 \mathrm{~h}$ post-dose). Subjects were discharged when either $\geq 90 \%$ of the administered radioactivity was recovered in excreta, or the excreta samples from 2 consecutive days contained $<1 \%$ of the administered radioactivity.

\subsection{Assessments}

Samples for total radioactivity concentration determination in whole blood, plasma, urine, and feces, and $\left[{ }^{14} \mathrm{C}\right]$ felcisetrag concentrations in plasma were collected pre-dose (within $30 \mathrm{~min}$ ) and at $0.5,1$ (at end of infusion), 1.5, 2, 3, $4,6,12,24,36,48,72,96,120,144$, and $168 \mathrm{~h}$ post-dose and every $24 \mathrm{~h}$ thereafter while the subject was confined. Blood samples for metabolite profiling were collected predose and at 1 (at end of infusion), 2, 4, 8, 12, 24, 48, 72, $96,120,144$, and $168 \mathrm{~h}$ post-dose and every $24 \mathrm{~h}$ thereafter while the subject was confined. Urine was collected pre-dose (spot sample -12 to $0 \mathrm{~h}$ ) and at $0-6,6-12,12-24,24-48$, 48-72, 72-96, 96-120, 120-144, and 144-168 h post-dose and every $24 \mathrm{~h}$ thereafter while the subject was confined. Feces were collected pre-dose (last stool before dosing), and all samples produced up to at least $168 \mathrm{~h}$ post-dose (pooled in 24-h intervals) and every $24 \mathrm{~h}$ thereafter were collected while the subject was confined.

\subsection{Radioactivity Determination}

Radioactivity concentrations in plasma, urine, and fecal extracts were determined by a Tri-Car Model 3100 TR liquid scintillation counter (Perkin Elmer) using $5 \mathrm{~mL}$ of scintillation fluid (Ultima Gold ${ }^{\mathrm{TM}}$; Perkin Elmer) or by accelerator mass spectrometry (AMS) quantization (see Supplemental Material Methods).

\subsection{Plasma Protein Binding}

Concentrations of $0.01,0.1$ and $1 \mu \mathrm{g} / \mathrm{mL}$ of $\left[{ }^{14} \mathrm{C}\right]$ felcisetrag were added to triplicate samples of plasma from mice, rats, dogs, and humans, under ambient conditions. The spiked samples were mixed well and incubated for $30 \mathrm{~min}$ at $37{ }^{\circ} \mathrm{C}$ in a water bath, and $100-\mu \mathrm{L}$ aliquots were measured by LSC. A 1-mL aliquot of each spiked sample was transferred into an ultra filtration apparatus and centrifuged at approximately $1500 \mathrm{~g}$ for $20 \mathrm{~min}$ at $37^{\circ} \mathrm{C}$ to obtain the filtrate. After centrifugation, a $50-\mu \mathrm{L}$ aliquot of each filtrate was measured by LSC. Calculations used to derive the plasma protein binding ratios are presented in Supplemental Methods.

\subsection{Felcisetrag Plasma Assays}

The concentrations of felcisetrag and its metabolites, M10 and M5, in human plasma were determined using a validated liquid chromatography-tandem mass spectrometry (LC-MS/ MS) method, as described in the Supplemental Material.

\subsection{Pharmacokinetics Analysis}

Pharmacokinetics analysis of felcisetrag, M10 and M5 in plasma and of radioactivity in blood and plasma were conducted by non-compartmental techniques using WinNonlin (v.6.1).

\section{Metabolite Profiling and Identification}

\subsection{Preparation of Pooled Plasma}

Plasma samples were pooled across all subjects using an area under the concentration-time curve (AUC) approach [9] across timepoints 0-168 h. Pre-dose and post-dose pooled plasma samples were extracted as follows: pooled plasma samples $(500 \mu \mathrm{L})$ underwent protein precipitation; reconstituted extracts $(\sim 300 \mu \mathrm{L})$ were spiked with the solution containing felcisetrag, M10 and M5 reference standards (15 $\mu \mathrm{L}$ of $1 \mathrm{mg} / \mathrm{mL}$ prepared in methanol); plasma and plasma extracts were analyzed by AMS and these data used to determine the extraction efficiency.

\subsection{Preparation of Pooled Urine}

Urine samples were pooled based on a ratio $(0.5 \%)$ of the total weight of the sample excreted at each time point. The pool was made to represent at least $95 \%$ of the total excreted ${ }^{14} \mathrm{C}$. A cross-subject pool was prepared by taking a constant proportion (1/25th) of each individual subject pool which were combined to obtain a representative pooled urine sample. A pre-dose cross-subject pool was prepared to serve as a system suitability sample and to allow background subtraction of the post-dose pool when analyzed by AMS. Pooled urine $(500 \mu \mathrm{L})$ was spiked with $1.0 \mathrm{mg} / \mathrm{mL}$ mixed reference standard (M10 and M5, 25 $\mu \mathrm{L}$ ). The sample was vortex-mixed and placed in the autosampler for HPLC-AMS analysis. 


\subsection{Preparation of Homogenized Feces}

Faeces homogenate samples were pooled based on the ratio of the total weight of the sample excreted at each time point. Homogenized feces samples were pooled by mixing a constant proportion $(0.5 \%)$ of the total weight of the fecal sample collected. The pool across $0-168 \mathrm{~h}$ captured $>95 \%$ of the total excreted ${ }^{14} \mathrm{C}$. A cross-subject pool was prepared by taking a constant proportion (1/25th) of each individual subject pool and combining. A pre-dose cross-subject pool was prepared to serve as a system suitability sample and to allow background subtraction of the post-dose pool when analyzed by AMS. Pre-dose and post-dose pooled homogenized feces samples were extracted as described in Supplemental Methods. Homogenized feces and feces extract were analyzed by AMS.

\subsection{Preparation of Samples, Standards and Controls for AMS Analysis and Metabolite Identification}

All samples and controls were graphitized and analyzed by AMS, as described in Supplemental Methods.

Metabolite identification using accurate mass full scan and product ion analysis was carried out in positive and negative ion mode using accurate mass full scan with targeted product ion data acquisition methods. The retention times, accurate mass extracted ion chromatograms, and product ion data (where available) were used to confirm the presence of felcisetrag, the additional supplied reference standards, and other predicted metabolites, e.g., hydroxylation, hydrolysis, desaturation, ketone formation, amide hydrolysis, and phase II conjugation (e.g., glucuronic acid and sulfate). Accurate mass full scan interrogation was used to identify presence of components by direct comparison with the AMS profiles. The AMS profiles were compared with the LC-MS/ MS data to confirm the identification of the major radioactive components.

\subsection{Evaluation of Direct or Time Dependent CYP Inhibition}

Human liver microsomes (mixed gender pool of 200 donors (100 male and 100 female, lot number 1210347); 0.0125, 0.05 or $0.1 \mathrm{mg} / \mathrm{mL}$ in $0.1 \mathrm{M}$ potassium phosphate buffer, $\mathrm{pH}$ 7.4; XenoTech) were incubated with CYP isoform-selective substrates and multiple concentrations of felcisetrag (0-30 $\mu \mathrm{M})$, as described in Supplemental Material Methods.

\subsection{Evaluation of Felcisetrag as an Inducer of Drug Metabolizing Enzymes}

CYP induction was evaluated by mRNA expression in three donors of primary cryopreserved human hepatocytes
(Supplementary Table 1). Hepatocytes were treated with hepatocyte culture medium containing six concentrations $(0,0.1,0.3,1,3,10$, or $30 \mu \mathrm{M})$ of felcisetrag. Positive controls were treated in parallel: omeprazole $(50 \mu \mathrm{M})$ for CYP1A2, phenobarbital $(750 \mu \mathrm{M})$ for CYP2B6, and rifampicin $(20 \mu \mathrm{M})$ for CYP3A4. Vehicle and negative controls were treated with hepatocyte culture medium containing $0.1 \%$ dimethyl sulfoxide (DMSO) and flumazenil $(25 \mu \mathrm{M})$, respectively. Hepatocytes were placed in a $95 \%$ air $/ 5 \% \mathrm{CO}_{2}$ incubator at $37{ }^{\circ} \mathrm{C}$ for 3 days $(72 \mathrm{~h})$, with daily replacement of hepatocyte culture medium containing the test article, positive controls, or vehicle. Cytotoxicity was evaluated using lactate dehydrogenase leakage and morphological changes.

Following treatment, hepatocytes were harvested with Buffer RLT reagent (Qiagen, Valencia, CA, USA) containing $\beta$-mercaptoethanol $(100: 1, \mathrm{v} / \mathrm{v})$ to isolate RNA, which was analyzed by real-time quantitative reverse transcription polymerase chain reaction to assess the effect of felcisetrag on mRNA levels using the same methods previously reported [10].

\subsection{CYP Reaction Phenotyping}

Human cDNA-expressed recombinant cytochrome P450 (rCYP) isoforms CYP1A2, 2B6, 2C8, 2C9, 2C19, 2D6, and 3A4 and insect control Supersomes ${ }^{\mathrm{TM}}$ (BD Biosciences, Woburn, MA, USA) were diluted with phosphate buffer $(0.1 \mathrm{M} ; \mathrm{pH} 7.4)$ to yield a concentration of $50 \mathrm{pmol} / \mathrm{mL}$ Supersomes ${ }^{\mathrm{TM}}(0.46 \mathrm{mg}$ total protein $/ \mathrm{mL}$ ) in the final incubation. The final concentration of felcisetrag in the incubation was 1 $\mu \mathrm{M}$. At designated timepoints, $0,10,20,30,40$, and $50 \mathrm{~min}$, a sample was removed for quantization of felcisetrag levels, as described in Supplemental Methods and reference [11].

\subsubsection{Contribution of CYP and Non-CYP to the In Vitro Metabolism of Felcisetrag by Human Liver $\mathrm{S9}$}

The contribution of CYP and non-CYP to the in vitro metabolic clearance of felcisetrag by human liver $\mathrm{S} 9(1 \mathrm{mg} / \mathrm{mL})$ was evaluated using typical inhibitors of CYP and esterase. In vitro intrinsic clearance of felcisetrag in human liver S9 with or without CYP inhibitors, 1-aminobenzotriazole (ABT, $1000 \mu \mathrm{M})$, troleandomycin (TRO, $50 \mu \mathrm{M}$ ), and esterase inhibitor, bis( $p$-nitrophenyl) phosphate (BNPP, $100 \mu \mathrm{M}$ ) was investigated to evaluate the relative contribution of CYP and non-CYP toward in vitro metabolism of felcisetrag. 


\subsection{Evaluation of Felcisetrag as a Substrate or Inhibitor of Transporters}

To determine whether felcisetrag is a substrate of clinically relevant transporters, the uptake of felcisetrag was evaluated with and without prototypical inhibitors following incubation at $37{ }^{\circ} \mathrm{C}$ using mock cells (HEK293 cells transfected with empty vector) and OATP1B1-, OATP1B3-, OAT1-, OAT3-, OCT2-, MATE1-, and MATE2-K expressing HEK293 cells, as described in Supplemental Methods. The same approach outlined above was used to evaluate felcisetrag as an inhibitor of transporters by monitoring the change in uptake clearance for selected substrates (Supplemental Table 2).

\section{Results}

\subsection{In Vitro Metabolism in Hepatocytes}

The chemical structure for $\left[{ }^{14} \mathrm{C}\right]$ felcisetrag is presented in Fig. 1. The in vitro metabolite profile of $\left[{ }^{14} \mathrm{C}\right]$ felcisetrag was evaluated using hepatocytes from mouse (M), rat (R), dog (D), and human (H). Felcisetrag was metabolized primarily through monooxygenation, hydroxylation, $N$-dealkylation, -demethoxycarbonylation, and dehydrogenation (Fig. 1, labeled H, R, D, and M). All metabolites generated in human hepatocytes were also observed in incubations with mouse, rat, and dog hepatocytes, suggesting that felcisetrag does not have any unique human metabolites. The metabolites observed from in vitro hepatocyte incubations were consistent with those observed in vivo (Fig. 1).

\subsection{Rat and Dog ADME}

\subsubsection{Rat Plasma Pharmacokinetics}

Plasma concentration-time profiles of radioactivity were investigated after single IV administration of $\left[{ }^{14} \mathrm{C}\right]$ felcisetrag at a dose of $0.5 \mathrm{mg} / \mathrm{kg}$ to fed male rats (Fig. 2A). After IV administration, plasma concentration of radioactivity was $0.133 \mu \mathrm{g}$ equiv. $/ \mathrm{mL}$ at $0.083 \mathrm{~h} \mathrm{C}_{5} \mathrm{~min}$ ), then decreased to $0.007 \mu \mathrm{g}$ equiv. $/ \mathrm{mL}$ by $8 \mathrm{~h}$ with a $t_{1 / 2}$ of $2.0 \mathrm{~h}$. The $\mathrm{AUC}_{0-24}$ was $0.263 \mu \mathrm{g}$ equiv. $\mathrm{h} / \mathrm{mL}$.

\subsection{Rat Excretion}

The urinary, fecal and expiratory excretion of radioactivity was investigated after single IV administration of $\left[{ }^{14} \mathrm{C}\right]$ felcisetrag at a dose of $0.5 \mathrm{mg} / \mathrm{kg}$ to fed male rats. The mean and standard deviation for excretions of radioactivity relative to the total dose into urine and feces by $168 \mathrm{~h}$ after administration were $32.7 \pm 9.6 \%$ and $66.2 \pm 9.6 \%$, respectively
(Fig. 2B). The biliary, urinary and fecal excretion of radioactivity was determined in bile duct cannulated fed male rats at the same dose level. The mean excretion and residual radioactivity relative to the total dose into the bile, urine, feces including gastrointestinal contents and carcass by $24 \mathrm{~h}$ after administration were $40.4 \%, 29.0 \%, 21.9 \%$, and $9.6 \%$, respectively (Fig. 2C). These results suggested that felcisetrag and derived metabolites were excreted into the bile, urine, and gastrointestinal tract after single IV administration to male rats, and that the excretion was almost complete.

\subsection{Metabolite Profiling in Rat}

The human-relevant metabolites observed in rat plasma and excreta are presented in Fig. 1. After IV administration of $\left[{ }^{14} \mathrm{C}\right]$ felcisetrag to rat, the $\mathrm{AUC}_{0-4 \mathrm{~h}}$ of felcisetrag was 0.125 $\mu \mathrm{g} \cdot \mathrm{h} / \mathrm{mL}$ (Fig. 2A). The ratio of the $\mathrm{AUC}_{0-4 \mathrm{~h}}$ of felcisetrag to total radioactivity was $79.1 \%$. Plasma samples were reanalyzed following the results from the hADME study to confirm the presence of human circulating metabolites in rat plasma. Metabolite concentrations were only detectable through $4 \mathrm{~h}$. The $\mathrm{AUC}_{0-4 \mathrm{~h}}$ of M1, M4/M5, and M10 were $0.001,0.005$, and $0.008 \mu$ g equiv. $\mathrm{h} / \mathrm{mL}$, respectively. The ratios of the $\mathrm{AUC}_{0-4 \mathrm{~h}}$ of M1, M4/M5, and M10 to that of the total radioactivity were $0.6 \%, 3.2 \%$, and $5.1 \%$, respectively. Felcisetrag was the major substance in rat plasma after IV administration. Following IV administration of felcisetrag, $30.8 \%$ of the dosed radioactivity was excreted into urine during $0-24 \mathrm{~h}$ after administration, and felcisetrag, M1, M4/ M5, and M10 comprised $73.4 \%, 1.6 \%, 8.1 \%$, and $9.4 \%$ of the urinary radioactivity, respectively. Unidentified metabolites comprised $7.5 \%$ of the urinary radioactivity, while $62.8 \%$ of the dosed radioactivity was excreted into feces during $0-48 \mathrm{~h}$ after administration, and felcisetrag, M1, M4/ M5, M7, and M10 comprised 31.1\%, 0.8\%, 14.8\%, 9.7\%, and $10.5 \%$ of the fecal radioactivity, respectively. Unidentified metabolites comprised $33.1 \%$ of the fecal radioactivity, and fecal extraction efficiency was incorporated into the reported data. Biliary excretion $(40.4 \%$ of the dosed radioactivity) occurred during $0-24 \mathrm{~h}$ after administration, and felcisetrag, M1, M12, M13, M4/M5, UN-1, M10, and UN-2 comprised $6.7 \%, 2.2 \%, 20.5 \%, 4.5 \%, 14.4 \%, 7.2 \%$, $12.1 \%$, and $15.8 \%$ of the biliary radioactivity, respectively. Unidentified metabolites comprised $16.6 \%$ of the biliary radioactivity.

\subsection{Dog Plasma Pharmacokinetics}

After IV administration, plasma concentration of felcisetragderived total radioactivity was $0.158 \mu \mathrm{g}$ equiv. $/ \mathrm{mL}$ at 0.083 $\mathrm{h}\left(\mathrm{C}_{5} \mathrm{~min}\right)$, then decreased to $0.002 \mu \mathrm{g}$ equiv. $/ \mathrm{mL}$ by $24 \mathrm{~h}$ with a $t_{1 / 2}$ of $3.7 \mathrm{~h}$. The $\mathrm{AUC}_{0-48 \mathrm{~h}}$ was $0.516 \mu \mathrm{g}$ equiv. $\mathrm{h} / \mathrm{mL}$. (Fig. 3A). 


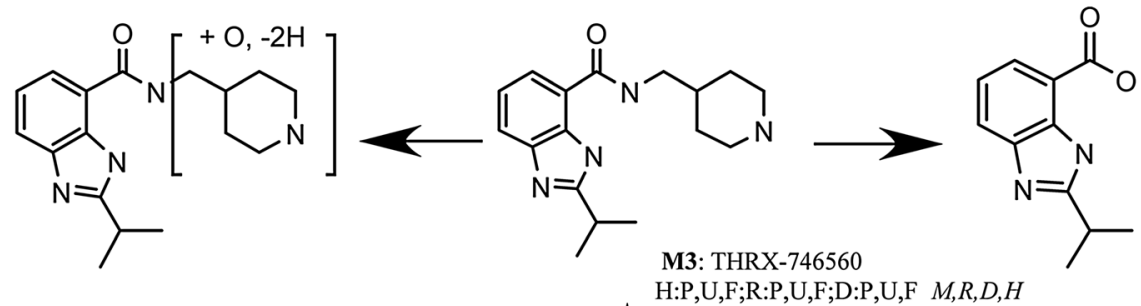

M15: Mono-hydroxy, desaturated (or keto) metabolite of Ndealkylated felcisetrag H:P (1h pool only)

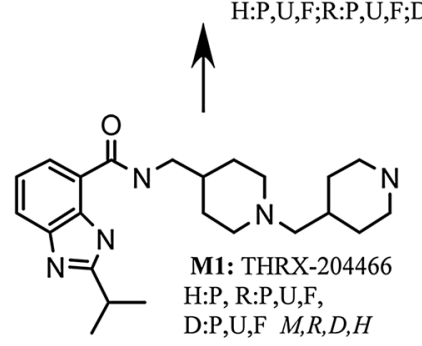

M14: Acid metabolite from amide hydrolysis of felcisetrag $\mathrm{H}: \mathrm{P}$ (1h pool only);D:P

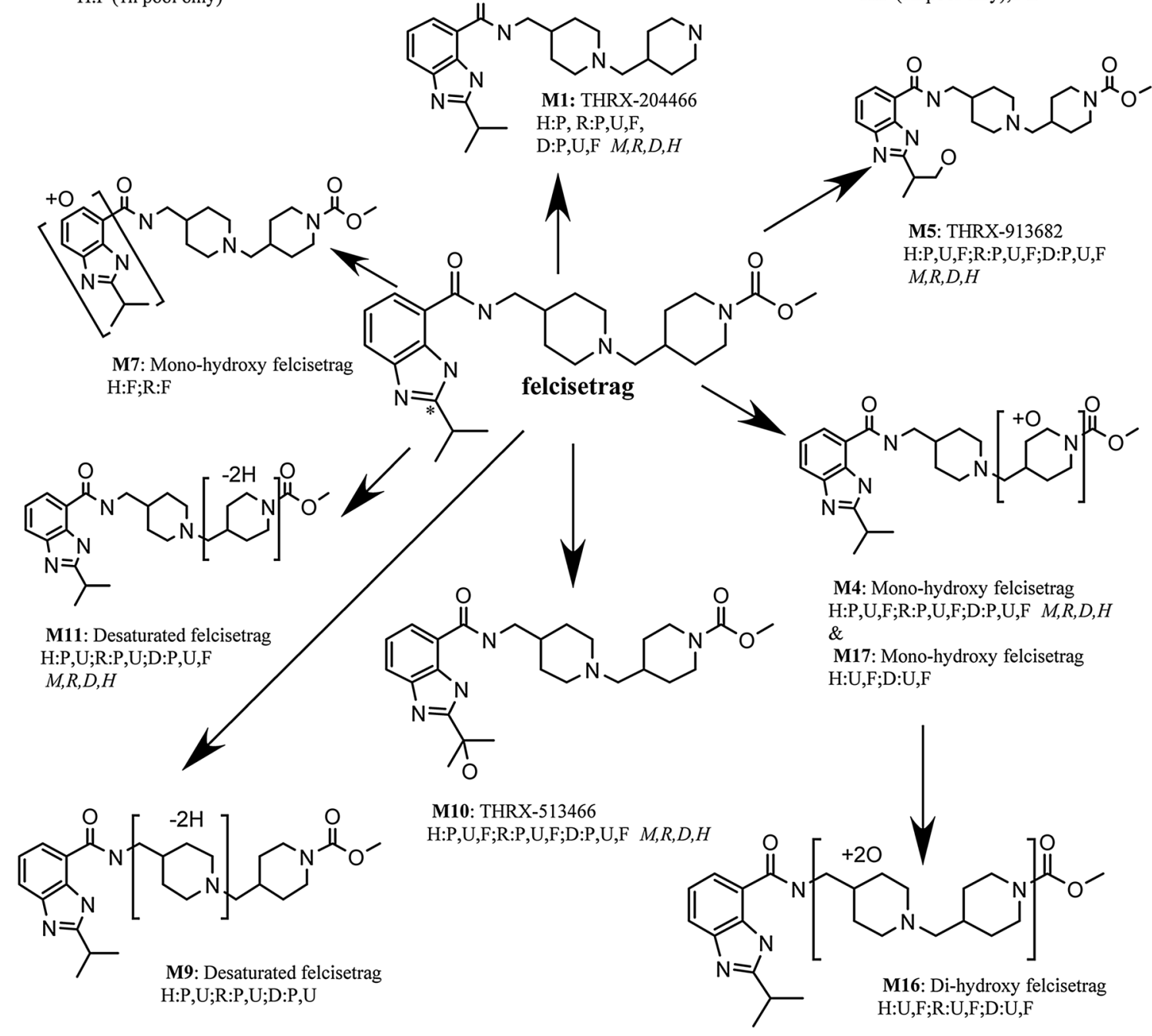

Fig. 1 Chemical structure of $\left[{ }^{14} \mathrm{C}\right]$ felcisetrag. The asterisk denotes the location of the ${ }^{14} \mathrm{C}$. Proposed metabolic scheme from in vitro and in vivo samples in rat $(R), \operatorname{dog}(D)$, and human $(H)$, in vitro results

\subsection{Dog Excretion}

The excretion of felcisetrag-derived radioactivity into urine and feces by $240 \mathrm{~h}$ after administration was $14.4 \%$ and $79.4 \%$ of the total dose, respectively, and the total excretion are denoted by italics $(M=$ mouse, $R=$ rat, $D=\operatorname{dog}$ and $H=$ human, hepatocytes). $P$ plasma, $F$ feces, $U$ urine

was $93.8 \%$ (Fig. 3B). These results indicated that felcisetragrelated substances were mainly excreted into feces after single IV administration of felcisetrag to male dogs. 
A

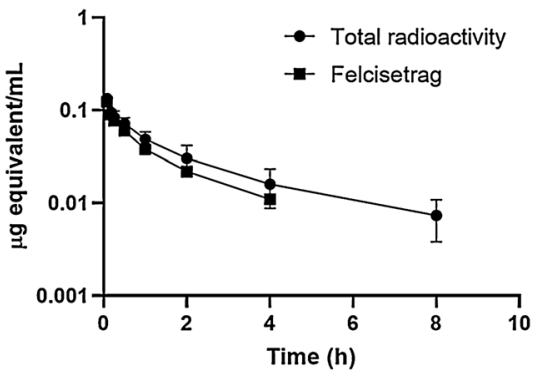

B

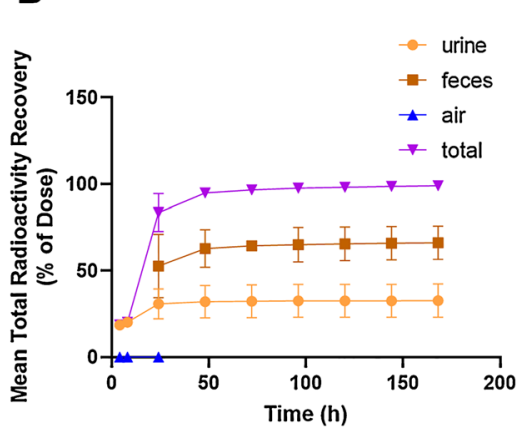

C

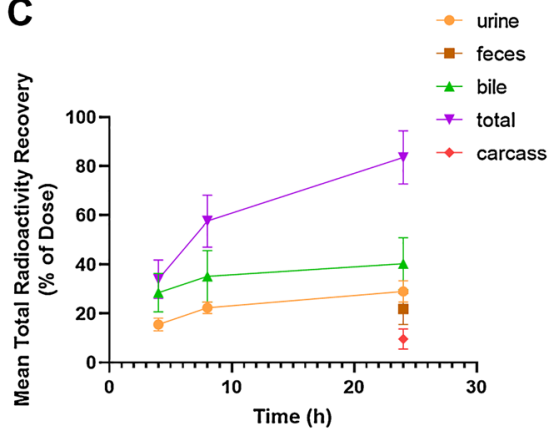

Fig. 2 Concentration-time profile in plasma and excreta following IV administration of $\left[{ }^{14} \mathrm{C}\right]$ felcisetrag $0.5 \mathrm{mg} / \mathrm{kg}$ to rats. Mean (SD) time course of radioactivity in plasma from rats $(n=3, \mathbf{A})$. Samples at 24 were below the limit of quantization (defined as $<2$-fold above the background level), felcisetrag levels were measured through $4 \mathrm{~h}$

\subsection{Metabolite Profiling in Dog}

The proposed human relevant metabolites observed in dog plasma and excreta are presented in Fig. 1. After IV administration of $\left[{ }^{14} \mathrm{C}\right]$ felcisetrag to dog the $\mathrm{AUC}_{0-4 \mathrm{~h}}$ of felcisetrag was $0.220 \mu \mathrm{g} \cdot \mathrm{h} / \mathrm{mL}$. The ratio of the $\mathrm{AUC}_{0-4 \mathrm{~h}}$ of felcisetrag to that of the total radioactivity was $81.2 \%$. The metabolite profile in dog plasma was evaluated post the results from the hADME study to ensure that the low level metabolites observed in human circulation were also formed in dog. The $\mathrm{AUC}_{0-4 \mathrm{~h}}$ of M1, M4/M5, and M10 were 0.001, 0.001, and $0.031 \mu \mathrm{g}$ equiv. $\mathrm{h} / \mathrm{mL}$, respectively. The ratios of the AUC 0-4h of M1, M4/M5, and M10 to that of the total radioactivity were $0.4 \%, 0.4 \%$, and $11.4 \%$, respectively, with $13.2 \%$ of the dosed radioactivity excreted into urine during $0-48$ $\mathrm{h}$ after administration, while felcisetrag, M1, M4/M5, and M10 comprised $46.2 \%, 1.5 \%, 3.0 \%$, and $37.1 \%$ of the urinary radioactivity, respectively. Unidentified metabolites comprised $12.2 \%$ of the urinary radioactivity, $74.4 \%$ of the dosed radioactivity was excreted into feces during $0-72 \mathrm{~h}$ after administration, and felcisetrag, M1, M4/M5, UN-1, and M10 comprised $7.8 \%, 13.7 \%, 3.2 \%, 7.1 \%$, and $53.5 \%$ of the fecal radioactivity, respectively. Unidentified metabolites comprised $14.7 \%$ of the fecal radioactivity. These results indicated that the dosed felcisetrag was mainly eliminated by metabolism after IV administration of felcisetrag to male dogs.

\subsection{Human ADME}

\subsubsection{Excretion}

Following a single 60 -min IV infusion of $0.5 \mathrm{mg}$ of felcisetrag containing a microtracer of $\left[{ }^{14} \mathrm{C}\right]$ felcisetrag $(1.5 \mu \mathrm{Ci})$ to healthy male subjects, the average radioactivity recovered to cover $>90 \%$ of the total AUC (area under the concentration-time curve), cumulative excretion of drug-related material in urine, expired air, and feces in intact rats $(n=3, \mathbf{B})$, cumulative excretion of drugrelated material in urine, bile, feces, and carcass in bile duct-canulated rats $(n=4, \mathbf{C})$. $h$ hour from excreta (urine + feces) was $84.4 \%$ by 14 days postdose (range of 77.7-91.3\%). This is within the generally acceptable range for human absorption, distribution, metabolism, and excretion (ADME) studies [12]. $\left[{ }^{14} \mathrm{C}\right]$ felcisetragrelated materials were cleared primarily through urine (mean $55.6 \%$ ) followed by feces (mean 28.8\%) (Fig. 4). Felcisetrag represented $66.3 \%$ of the radioactivity $\left(\mathrm{AUC}_{\infty}\right)$ in plasma, with the remaining radioactivity distributed amongst multiple minor metabolites of felcisetrag.

\subsection{Human Plasma Metabolite Profile}

Plasma was pooled up to $168 \mathrm{~h}$ post-dose per subject in a time-proportional manner to yield $\mathrm{AUC}_{168 \mathrm{hr}}$ proportional concentrations [9]. The pooling of plasma samples up to 168 h post-dose corresponded to between 2 and 3 half-lives ( $t_{1 / 2}$ $=70 \mathrm{~h}$ ) of total radioactivity in plasma. The pooled plasma samples were extracted for subsequent analysis by LC-AMS. The extraction efficiency across the pooled plasma from the 6 subjects ranged from 77.3 to $88.3 \%$. Among the plasma analyzed from 6 subjects, a total of 7-17 radiolabeled peaks were detected by AMS (including felcisetrag) with no single metabolite peak greater than $6 \%$ of the total plasma radioactivity in any individual subject (Table 1). Felcisetrag accounted for $74.3 \%$ (mean of 6 subjects; range 63.9-85.4\%) of the total plasma radioactivity, and was the major circulating component. The metabolites observed in plasma were a result of hydrolysis of the carbamate moiety, $\mathrm{N}$-dealkylation of the piperidine moiety, oxidation and/or desaturation of felcisetrag, or a combination of these pathways. Metabolites M14 and M15 were identified in plasma by LC/MS/MS but not detected in the plasma ${ }^{14} \mathrm{C}$-radioactivity profiles, hence they are trace-level metabolites. Several minor metabolites that were detected in the plasma ${ }^{14} \mathrm{C}$-radioactivity profiles were not identified by LC/MS/MS. The peak area for 
A

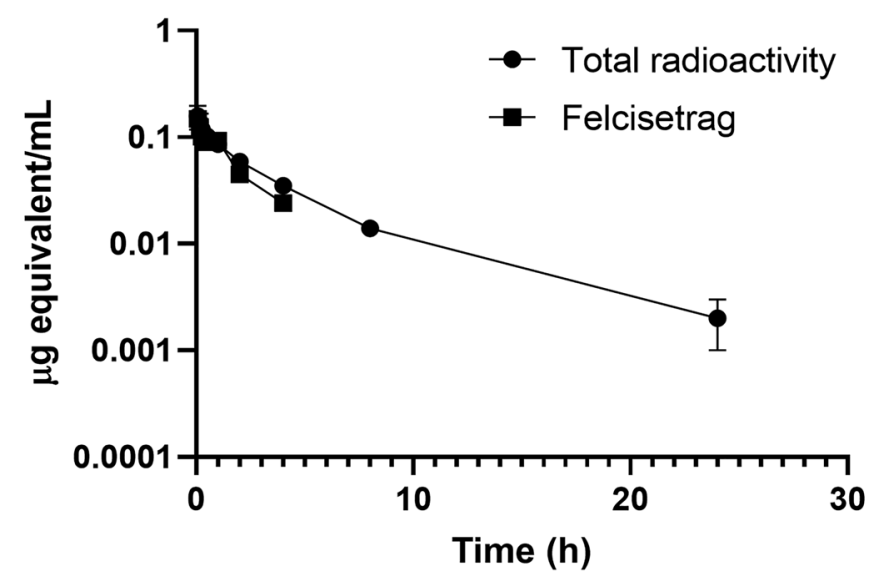

Fig. 3 Concentration-time profile in plasma and excreta following IV administration of $\left[{ }^{14} \mathrm{C}\right]$ felcisetrag $0.5 \mathrm{mg} / \mathrm{kg}$ to dogs. Mean (SD) time course of radioactivity in plasma from $\operatorname{dog}(n=4, \mathbf{A})$. Plasma samples were below the limit of detection, defined as $<2$-fold above

metabolites M10 and M11 could not be conclusively determined as the fractions containing these metabolites were combined and counted as 1 single fraction. The proposed structures are displayed in Fig. 1 and Supplemental Table 3, and key observed fragment ions are displayed in Supplemental Table 4. Representative radio and UV chromatograms from human plasma samples are displayed in Fig. 5A.

\subsection{Human Urine and Faeces Metabolite Profile}

Urine and feces were pooled across subjects and from 0-24 $\mathrm{h}$ up to $144-168 \mathrm{~h}$ collection intervals to generate a single $0-168 \mathrm{~h}$ pooled sample. The pooling over $0-168 \mathrm{~h}$ accounted for more than $97 \%$ and $96 \%$ of the total dose recovered in urine and feces, respectively, over the entire study duration. In $0-168 \mathrm{~h}$ pooled urine and feces, 23 and 21 radiolabeled peaks, respectively, were detected by AMS. The total metabolites and felcisetrag recovered in urine and feces as a percent of dose administered are presented in Table 1. Felcisetrag accounted for $37.4 \%$ and $11.5 \%$ of the total dose administered, and was the primary component in urine and in feces, respectively. When normalized for $100 \%$ recovery, i.e., corrected from $84.4 \%$, the fraction of felcisetrag recovered in urine was $44.3 \%$, and the fraction recovered in feces (i.e., biliary excretion) was $13.7 \%$. Considering the sum of the total recovered metabolites, the fraction of clearance through metabolism was estimated to be 0.420 (i.e., $29.9 \%$ of dose was excreted as identified metabolites and
B

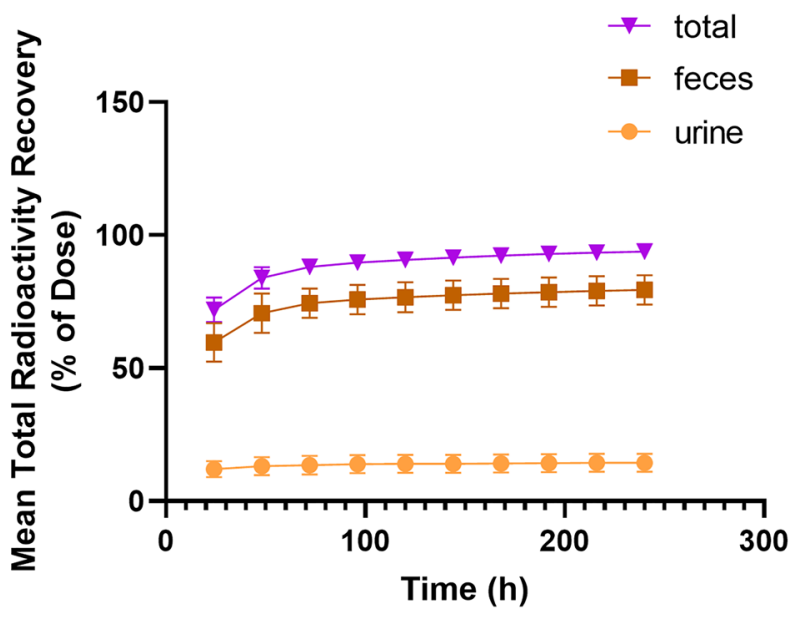

the background level. Felcisetrag levels were measured from samples up to $4 \mathrm{~h}$. Cumulative excretion of drug-related material in urine and feces in $\operatorname{dog}(n=4, \mathbf{B})$. $h$ hour

unidentified metabolites accounted for a cumulative total of $5.72 \%$ and $6.42 \%$ in urine and feces, respectively). All metabolites, including any unidentified ${ }^{14} \mathrm{C}$-radiolabeled peaks, were considered minor, with $\mathrm{M} 3$ excreted at $4.0 \%$ and $7.4 \%$ of the dose administered in urine and feces, respectively, representing the most abundant metabolite. All other metabolites were detected at $<4 \%$ of the total administered dose. Overall, in urine and feces combined, felcisetrag accounted for $58 \%$ of the total dose excreted. Most of the remaining dose was accounted for by hydrolysis of the carbamate moiety and oxidative metabolism pathways. Overall, felcisetrag was metabolized via hydrolysis of the carbamate moiety, $N$-dealkylation of the piperidine moiety, oxidation of the isopropyl or piperidine moieties, and/or a combination of these pathways with further oxidation of the primary metabolites. Representative radio and UV chromatograms from human urine and fecal samples are displayed in Fig. 5B and $\mathrm{C}$, respectively. All metabolites detected in the metabolic profiling in human were also detected in nonclinical species (Table 1; Fig. 1).

\subsection{Plasma Protein Binding}

The protein binding of ${ }^{14} \mathrm{C}$-felcisetrag was assessed by ultra filtration over the concentration range $0.001-1 \mu \mathrm{g} / \mathrm{mL}$. Felcisetrag was moderately to highly protein-bound and was not dependent on concentration. The percentage of plasma protein binding at $1 \mu \mathrm{g} / \mathrm{mL}$ was $95.2 \%, 76.5 \%, 70.7 \%$, and 
Fig. 4 Concentration-time profile in excreta following IV administration of $\left[{ }^{14} \mathrm{C}\right]$ felcisetrag $0.5 \mathrm{mg}$ to healthy human subjects. Mean (SD) time course of cumulative excretion of drug-related material in urine and feces following intravenous (IV) administration of ${ }^{14} \mathrm{C}$-felcisetrag to healthy human subjects $(n=6)$

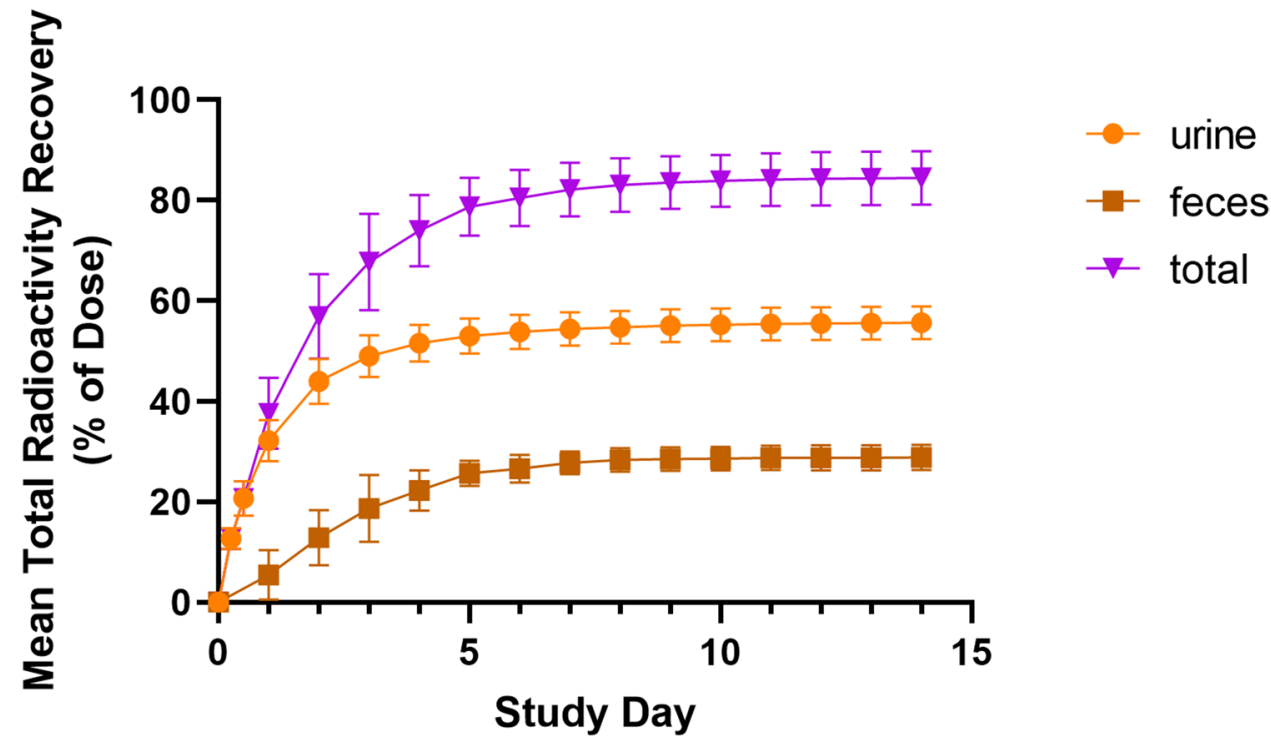

Table 1 Summary of metabolites of $\left[{ }^{14} \mathrm{C}\right]$ felcisetrag observed in $0-168$-h plasma, urine, and fecal samples following administration of a single $0.5 \mathrm{mg}$ IV dose of $\left[{ }^{14} \mathrm{C}\right]$ felcisetrag to human

\begin{tabular}{|c|c|c|c|c|c|c|}
\hline Component & $\begin{array}{l}\text { Molecular } \\
\text { weight }(\mathrm{Da})^{\mathrm{a}}\end{array}$ & Molecular formula & $\begin{array}{l}\text { Nominal reten- } \\
\text { tion time }(\min )^{b}\end{array}$ & Plasma & Urine & Faeces \\
\hline M1: THRX-204466 & 397 & $\mathrm{C}_{23} \mathrm{H}_{35} \mathrm{ON}_{5}$ & 8.0 & $\checkmark$ & $\checkmark$ & $x$ \\
\hline M3: THRX-746560 & 300 & $\mathrm{C}_{17} \mathrm{H}_{24} \mathrm{ON}_{4}$ & 12.0 & $\checkmark$ & $\checkmark$ & $\checkmark$ \\
\hline M14: acid metabolite from amide hydrolysis of felcisetrag & 204 & $\mathrm{C}_{11} \mathrm{H}_{12} \mathrm{O}_{2} \mathrm{~N}_{2}$ & 14.9 & $\checkmark$ & $\checkmark$ & $x$ \\
\hline $\begin{array}{l}\text { M15: mono-hydroxy, desaturated (or keto) metabolite of } \\
N \text {-dealkylated felcisetrag }\end{array}$ & 314 & $\mathrm{C}_{17} \mathrm{H}_{22} \mathrm{O}_{2} \mathrm{~N}_{4}$ & 21.4 & $\checkmark$ & $\checkmark$ & $x$ \\
\hline M16: di-hydroxy felcisetrag & 487 & $\mathrm{C}_{25} \mathrm{H}_{37} \mathrm{O}_{5} \mathrm{~N}_{5}$ & 24.1 & $x$ & $\checkmark$ & $\checkmark$ \\
\hline M5: THRX-913682 & 471 & $\mathrm{C}_{25} \mathrm{H}_{37} \mathrm{O}_{4} \mathrm{~N}_{5}$ & 24.6 & $\checkmark$ & $\checkmark$ & $\checkmark$ \\
\hline M4: mono-hydroxy felcisetrag & 471 & $\mathrm{C}_{25} \mathrm{H}_{37} \mathrm{O}_{4} \mathrm{~N}_{5}$ & 24.6 & $\checkmark$ & $\checkmark$ & $\checkmark$ \\
\hline M17: mono-hydroxy felcisetrag & 471 & $\mathrm{C}_{25} \mathrm{H}_{37} \mathrm{O}_{4} \mathrm{~N}_{5}$ & 27.2 & $\checkmark$ & $\checkmark$ & $\checkmark$ \\
\hline M7: mono-hydroxy felcisetrag & 471 & $\mathrm{C}_{25} \mathrm{H}_{37} \mathrm{O}_{4} \mathrm{~N}_{5}$ & 29.4 & $x$ & $x$ & $\checkmark$ \\
\hline M9: desaturated felcisetrag & 453 & $\mathrm{C}_{25} \mathrm{H}_{35} \mathrm{O}_{3} \mathrm{~N}_{5}$ & 36.3 & $\checkmark$ & $\checkmark$ & $x$ \\
\hline felcisetrag & 455 & $\mathrm{C}_{25} \mathrm{H}_{37} \mathrm{O}_{3} \mathrm{~N}_{5}$ & 39.6 & $\checkmark$ & $\checkmark$ & $\checkmark$ \\
\hline M10: THRX-513466 & 471 & $\mathrm{C}_{25} \mathrm{H}_{37} \mathrm{O}_{4} \mathrm{~N}_{5}$ & 44.4 & $\checkmark$ & $\checkmark$ & $\checkmark$ \\
\hline M11: desaturated felcisetrag & 453 & $\mathrm{C}_{25} \mathrm{H}_{35} \mathrm{O}_{3} \mathrm{~N}_{5}$ & 45.6 & $\checkmark$ & $\checkmark$ & $x$ \\
\hline
\end{tabular}

${ }^{a}$ Molecular weights refer to unlabeled components

${ }^{\mathrm{b}}$ Nominal retention times from accurate mass extracted ion chromatograms

Component confirmed as present

Component not present by LC-MS

98.6\% in mouse, rat, dog, and human plasma, respectively. In vitro protein binding of $\left[{ }^{14} \mathrm{C}\right]$ felcisetrag over the range of $0.01-1 \mu \mathrm{g} / \mathrm{mL}$ to $4 \%$ human serum albumin (HSA), $0.05 \%$ $\alpha 1$-acid glycoprotein (AGP), and 4\% HSA/0.05\% AGP demonstrated preferential binding to HSA.

\subsection{CYP Phenotyping}

Felcisetrag was mainly metabolized by CYP3A4, as demonstrated by near complete inhibition by ABT and TRO (Table 2). Since BNPP showed minimal effect, esterases do not play a significant role in the metabolism of felcisetrag. 
A 1.

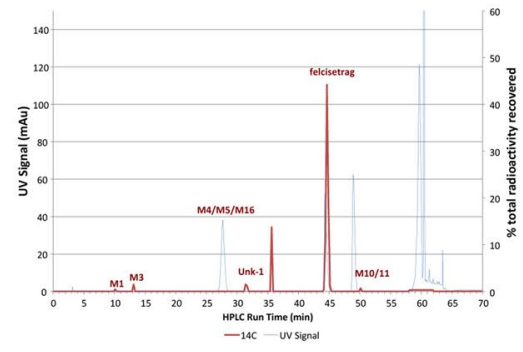

4.

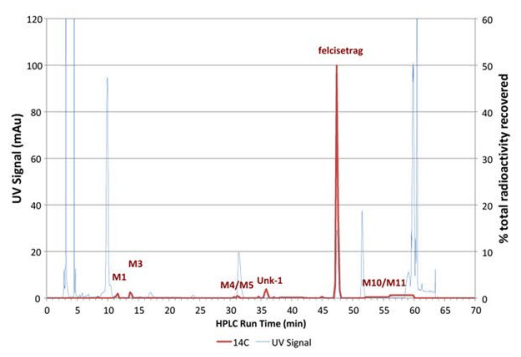

2.

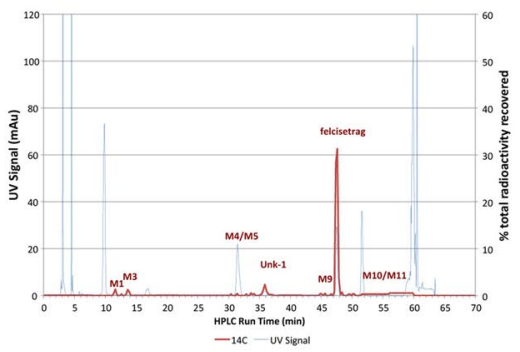

5.

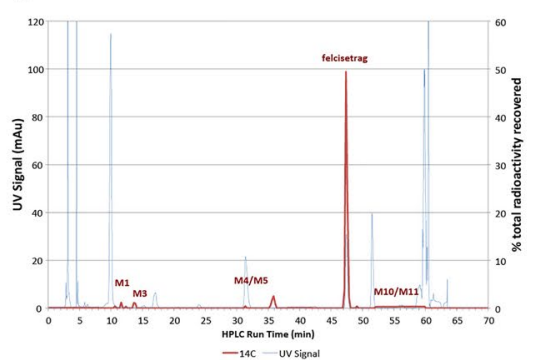

3.

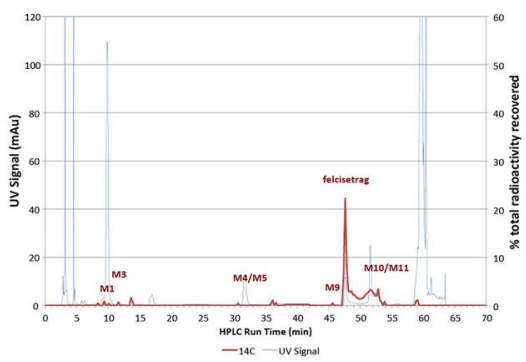

6.

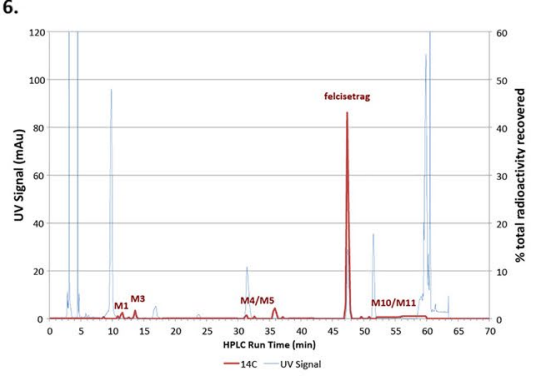

Fig. 5 Representative radiochromatograms of $\left[{ }^{14} \mathrm{C}\right]$ felcisetrag in: A individual pooled plasma $0-168 \mathrm{~h}$ (subjects 1-6); $\mathbf{B}$ all subjects pooled urine $0-168 \mathrm{~h}$; and $\mathbf{C}$ all subject pooled feces $0-168 \mathrm{~h}, n=6$.
$U V$ ultraviolet, $m A u$ milli-absorbance unit, $H P L C$ high performance liquid chromatography, min minute, $M$ followed by a number metabolite of felcisetrag

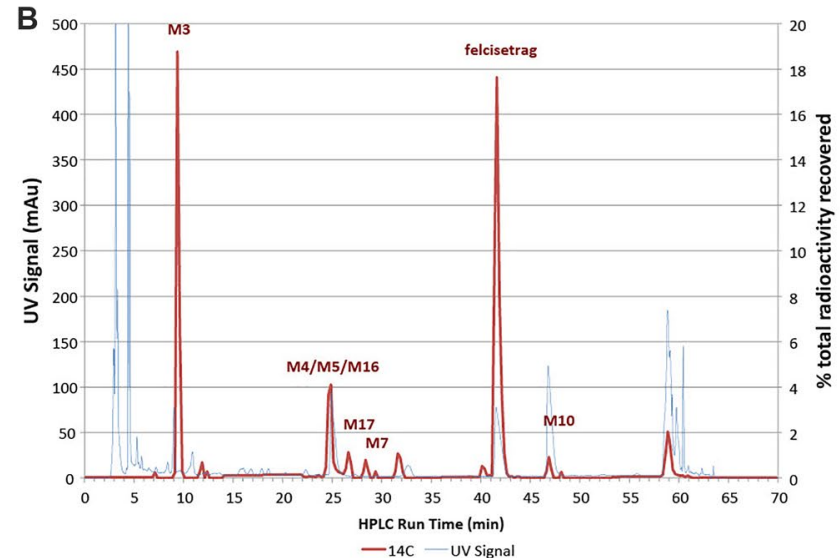

Fig. 5 (continued)

In human, a trace level of hydrolytic product was detected, but the identity of the enzyme involved was not elucidated. The relative contribution ratio of CYP3A4 to the in vitro metabolism of felcisetrag was $97.9 \%$, and the contribution of all other CYPs evaluated (CYP1A2, 2B6, 2C8, 2C9, 2C19, and 2D6) was minimal (Table 2).

\subsection{CYP Inhibition}

The potential for felcisetrag $(0.03,0.1,0.3,1,3,10$, and $30 \mu \mathrm{M})$ to inhibit marker activities of $7 \mathrm{CYP}$ isoforms (CYP1A2, CYP2B6, CYP2C8, CYP2C9, CYP2C19,

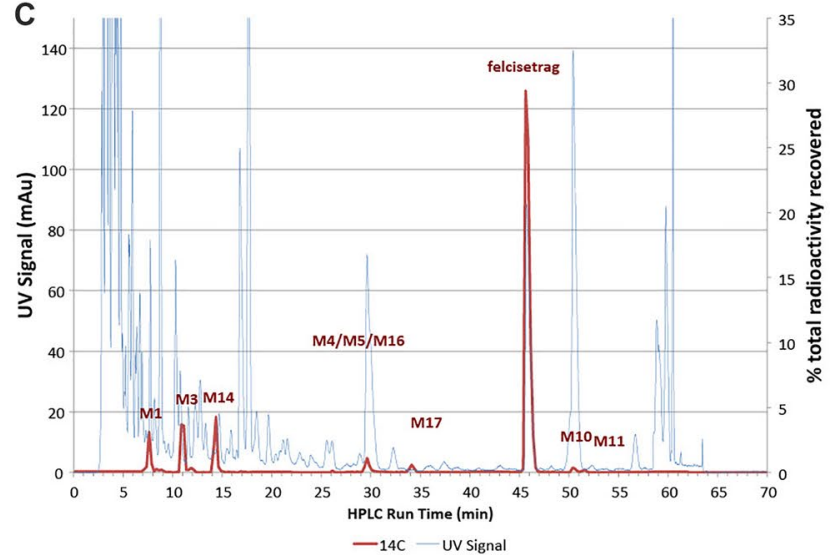

CYP2D6, and CYP3A4/5) were examined in human liver microsomes. Under the experimental conditions examined, there was less than $50 \%$ direct inhibition of CYP1A2, CYP2B6, CYP2C8, CYP2C9, CYP2C19, CYP2D6, and CYP3A4/5 by felcisetrag, and the $\%$ of inhibition observed at $30 \mu \mathrm{M}$ were $4.5 \%, 14 \%, 14 \%, 20 \%, 33 \%, 21 \%, 17 \%$, and $23 \%$, respectively. Therefore, $\mathrm{IC}_{50}$ values were $>30$ $\mu \mathrm{M}$ (Table 3). In addition, there was no evidence of timeor metabolism-dependent inhibition of any of the CYP enzymes evaluated by felcisetrag (Table 3). 


\subsection{CYP Induction}

The potential for felcisetrag to induce pathways known to regulate expression of drug-metabolizing enzymes and transporters was investigated using cultured hepatocytes prepared from three separate human donors. Positive control inducers were used to confirm that the hepatocytes were responsive to induction. Felcisetrag did not show activation or agonism of AhR or PXR in any of the human hepatocyte donors investigated. In one donor, there was an increase in CYP2B6 mRNA levels $>2$-fold at $30 \mu \mathrm{M}$ (Table 4). The induction parameters were estimated with a three-parameter logistic function to be (least squares estimate and standard error) $\mathrm{EC}_{50}=1.39(0.580) \mu \mathrm{M}$ and $E_{\max }=2.11-(0.115)$ fold. The concentration resulting in 2-fold induction (F2) was estimated to be $8.1 \mu \mathrm{M}$. When considering the recommendations made in regulatory guidance documents and the estimated initial concentration of felcisetrag following IV infusion of $0.5 \mathrm{mg}(0.013 \mu \mathrm{M}$ total, $\mathrm{Fu}=0.014)$, clinical induction of CYP2B6 can be excluded. Based on the totality of these data, felcisetrag is unlikely to mediate DDI via induction of drug-metabolizing enzymes.

\subsection{Transporter Substrate or Inhibition}

Results from Caco-2 studies indicated that felcisetrag is a substrate for P-gp and not BCRP and has high permeability in the absence of P-gp efflux. Felcisetrag showed weak in vitro inhibition of $\mathrm{P}-\mathrm{gp}$ with an $\mathrm{IC}_{50}$ value greater than 10 $\mu \mathrm{M}$. Felcisetrag is not a substrate of OATP1B1, OATP1B3, OAT1, OAT3, OCT2, MATE1, or MATE2-K. Felcisetrag did not inhibit the OATP1B1-, OATP1B3-, OAT1-, OAT3-, OCT1-, OCT2-, or BSEP-mediated transport of typical substrates more than $50 \%$ up to the maximum concentration of $10 \mu \mathrm{M}$, hence the $\mathrm{IC}_{50}$ value is $>10 \mu \mathrm{M}$. Felcisetrag inhibited the MATE1- and MATE2-K-mediated transport with $\mathrm{IC}_{50}$ values of $0.988 \mu \mathrm{M}$ and $4.84 \mu \mathrm{M}$, respectively (Fig. 6). The recommendations made in the regulatory guidance documents were applied to evaluate the potential clinical relevance of this in vitro inhibition [13-15]. Considering the unbound maximal concentration observed following a 0.5 -mg IV infusion of felcisetrag is $0.00018 \mu \mathrm{M}$, clinically relevant inhibition of MATE1- or MATE2-K substrates is unlikely.

\section{Discussion}

The metabolism and excretion properties of felcisetrag have been evaluated in nonclinical models and in a mass balance study conducted in humans. The studies were designed to confirm that human-relevant metabolites were also observed in nonclinical species, and to aid in informing the design of subsequent clinical studies. The metabolism of felcisetrag was evaluated in mouse, rat, dog, and human hepatocytes, resulting in the identification of potentially pharmacologically active monooxygenation metabolites M10 and M5 and an $N$-dealkylation metabolite M3 (Table 5).

Characterization of the pharmacokinetics, distribution, metabolism, and excretion (DME) in rat and dog for felcisetrag was conducted to support nonclinical safety studies and human clinical studies. These studies revealed that, following IV administration of $\left[{ }^{14} \mathrm{C}\right]$ felcisetrag to rats and dogs, the elimination of radioactivity was largely via feces (66.2\% and $79.4 \%$ of dose, respectively) by biliary excretion/ direct luminal secretion, considering the rat BDC data, with urinary excretion accounting for $32.7 \%$ and $14.4 \%$ in rats and dogs, respectively. After an IV administration in bile duct-cannulated rats, the biliary excretion was $40.4 \%$ over 24 h. In rat and dog plasma, unchanged felcisetrag constituted $79.1 \%$ and $81.2 \%$, respectively, of the plasma radioactivity $\mathrm{AUC}_{0-4 \mathrm{~h}}$. In rats and dogs, the elimination of felcisetrag was extensive via metabolism. In order to investigate these attributes in human, a single dose of $0.5 \mathrm{mg}$ was chosen for the following reasons: a $0.5-\mathrm{mg}$ IV dose was likely to be in the therapeutic range, and, based on previous clinical experience, had an acceptable safety profile in healthy subjects. The use of a microtracer was selected because investigations revealed that $4.7 \mathrm{MBq} / \mathrm{mg}(\sim 127 \mu \mathrm{Ci} / \mathrm{mg})$ of ${ }^{14} \mathrm{C}$ felcisetrag was unstable at $-80{ }^{\circ} \mathrm{C}$ over 4 months and therefore could

Table 2 In vitro phenotyping

\begin{tabular}{lllll}
\hline CYP isoform & $\begin{array}{l}\mathrm{CL}_{\text {int }}(\mu \mathrm{L} / \mathrm{min} / \mathrm{pmol} \\
\mathrm{CYP})\end{array}$ & $\begin{array}{l}\text { Enzyme abundance } \\
(\mathrm{pmol} / \mathrm{mg} \text { protein })\end{array}$ & $\begin{array}{l}\mathrm{CL}_{\text {int }}(\mu \mathrm{L} / \mathrm{min} / \mathrm{mg} \\
\text { protein })\end{array}$ & $\%$ contribution \\
\hline CYP1A2 & 0 & 39 & 0 & 0 \\
CYP2B6 & 0 & 16 & 0 & 0 \\
CYP2C8 & 0 & 22.4 & 0 & 0 \\
CYP2C9 & 0 & 61 & 0 & 0 \\
CYP2C19 & 0.0266 & 11 & 0.293 & 0.702 \\
CYP2D6 & 0.0446 & 12.6 & 0.562 & 1.35 \\
CYP3A4 & 0.439 & 93 & 40.8 & 97.9 \\
\hline
\end{tabular}

$C L_{\text {int }}$ intrinsic clearance, $C Y P$ cytochrome $\mathrm{P} 450$ 
Table 3 In vitro direct, time- and metabolism-dependent inhibition results

\begin{tabular}{|c|c|c|c|c|c|c|c|c|}
\hline \multirow[t]{3}{*}{ CYP isoform } & \multirow[t]{3}{*}{ Substrate } & \multirow{2}{*}{\multicolumn{2}{|c|}{$\frac{\text { Direct inhibition }}{\text { Zero-min preincubation }}$}} & \multirow{2}{*}{\multicolumn{2}{|c|}{$\begin{array}{l}\text { Time-dependent inhibition } \\
\text { 30-min preincubation without } \\
\text { NADPH }\end{array}$}} & \multicolumn{3}{|c|}{ Metabolism-dependent inhibition (MDI) } \\
\hline & & & & & & \multicolumn{2}{|c|}{$\begin{array}{l}\text { 30-min preincubation with } \\
\text { NADPH }\end{array}$} & \multirow[t]{2}{*}{$\begin{array}{l}\text { Potential } \\
\text { for MDI? }\end{array}$} \\
\hline & & $\mathrm{IC}_{50}(\mu \mathrm{M})$ & $\begin{array}{l}\% \text { inhibition } \\
\text { observed at } 30 \\
\mu \mathrm{M}\end{array}$ & $\mathrm{IC}_{50}(\mu \mathrm{M})$ & $\begin{array}{l}\% \text { inhibition } \\
\text { observed at } 30 \\
\mu \mathrm{M}\end{array}$ & $\mathrm{IC}_{50}(\mu \mathrm{M})$ & $\begin{array}{l}\% \text { inhibition } \\
\text { observed at } 30 \\
\mu \mathrm{M}\end{array}$ & \\
\hline CYP1A2 & Phenacetin & $>30$ & 4.5 & $>30$ & 3.5 & $>30$ & 4.9 & No \\
\hline CYP2B6 & Efavirenz & $>30$ & 14 & $>30$ & 6.9 & $>30$ & 6.2 & No \\
\hline CYP2C8 & Amodiaquine & $>30$ & 14 & $>30$ & 6.5 & $>30$ & 17 & No \\
\hline CYP2C9 & Diclofenac & $>30$ & 20 & $>30$ & 15 & $>30$ & 20 & No \\
\hline CYP2C19 & $S$-Mephenytoin & $>30$ & 33 & $>30$ & 27 & $>30$ & 30 & No \\
\hline CYP2D6 & Dextromethorphan & $>30$ & 21 & $>30$ & 12 & $>30$ & 13 & No \\
\hline CYP3A4/5 & Midazolam & $>30$ & 17 & $>30$ & 12 & $>30$ & 23 & No \\
\hline CYP3A4/5 & Testosterone & $>30$ & 23 & $>30$ & 14 & $>30$ & 23 & No \\
\hline
\end{tabular}

$I C_{50}$ the half-maximal inhibitory concentration, $N A D P H$ reduced nicotinamide adenine dinuclotide phosphate, $M D I$ metabolism dependent inhibition, $C Y P$ cytochrome $\mathrm{P} 450$

not be used to support ${ }^{14} \mathrm{C}$ hADME studies. Traditional doses of $3.7 \mathrm{MBq} /$ person $(100 \mu \mathrm{Ci} /$ person $)$ would require a specific activity of $7.4 \mathrm{MBq} / \mathrm{mg}(\sim 200 \mu \mathrm{Ci} / \mathrm{mg})$ for a 0.5 $\mathrm{mg}$ dose, could lead to radiolysis, and hence were not feasible. The radioactive burden from approximately $1.5 \mu \mathrm{Ci}$ (0.055 MBq) of total ${ }^{14} \mathrm{C}$ administered per subject used in the human mass balance study was considered to pose negligible additional risk above the background cosmic radiation and the stability of the radiolabeled drug was sufficient to complete the mass balance study. In order to ensure assay sensitivity for total radioactivity, absolute quantization, and metabolite profiling, AMS was selected for analysis. Results from the human mass balance study indicated that a large percentage of circulating radioactivity was associated with unchanged felcisetrag: the mean exposure $\left(\mathrm{AUC}_{\infty}\right)$ ratio for felcisetrag to total radioactivity was 0.642 (ranging from 0.58 to 0.78 ). These data agree with the plasma metabolite profiling using AMS. Felcisetrag was the major circulating component at $74.3 \%$ (mean of 6 subjects; range $63.9-85.4 \%$ ) of the total plasma radioactivity. A total of 12 metabolites of felcisetrag were characterized in plasma, urine, and feces. Felcisetrag was metabolized primarily via hydrolysis,

Table 4 Felcisetrag as an inducer of drug-metabolizing enzyme pathways

\begin{tabular}{|c|c|c|c|c|c|c|c|c|c|}
\hline \multirow[t]{3}{*}{ Felcisetrag $(\mu \mathrm{M})$} & \multicolumn{3}{|l|}{ CYP1A2 } & \multicolumn{3}{|l|}{ CYP2B6 } & \multicolumn{3}{|l|}{ CYP3A4 } \\
\hline & \multicolumn{3}{|c|}{ Fold induction } & \multicolumn{3}{|c|}{ Fold induction } & \multicolumn{3}{|c|}{ Fold induction } \\
\hline & $\mathrm{HC} 10-23^{\mathrm{b}}$ & $\mathrm{HC} 7-12^{\mathrm{b}}$ & $\mathrm{HC} 7-5^{\mathrm{b}}$ & $\mathrm{HC} 10-23^{\mathrm{b}}$ & $\mathrm{HC} 7-12^{\mathrm{b}}$ & $\mathrm{HC} 7-5^{\mathrm{b}}$ & $\mathrm{HC} 10-23^{\mathrm{b}}$ & $\mathrm{HC} 7-12^{\mathrm{b}}$ & $\mathrm{HC}-5^{\mathrm{b}}$ \\
\hline 0 & 1.00 & 1.00 & 1.00 & 1.00 & 1.00 & 1.00 & 1.00 & 1.00 & 1.00 \\
\hline 0.1 & 1.09 & 0.913 & 0.891 & 0.783 & 1.02 & 1.17 & 1.200 & 1.07 & 1.00 \\
\hline 0.3 & 0.847 & 0.755 & 0.654 & 0.902 & 0.990 & 1.32 & 0.921 & 0.900 & 0.884 \\
\hline 1 & 0.947 & 0.589 & 0.575 & 1.01 & 1.14 & 1.46 & 1.16 & 0.907 & 0.718 \\
\hline 3 & 0.804 & 0.542 & 0.653 & 1.06 & 1.12 & 1.70 & 0.90 & 0.824 & 0.861 \\
\hline 10 & 0.833 & 0.308 & 0.682 & 1.35 & 1.02 & 1.82 & 1.20 & 0.769 & 1.01 \\
\hline 30 & 0.718 & 0.357 & 0.779 & 1.54 & 1.04 & 2.22 & 1.54 & 1.22 & 1.37 \\
\hline Flumazenil $(25 \mu \mathrm{Mol} / \mathrm{L})$ & 0.911 & 0.654 & 0.941 & 1.11 & 1.19 & 1.13 & 0.959 & 0.940 & 1.00 \\
\hline Prototypical inducer $^{\mathrm{a}}$ & 47.9 & 18.2 & 17.0 & 8.19 & 10.8 & 14.4 & 16.90 & 12.8 & 9.95 \\
\hline
\end{tabular}

${ }^{\mathrm{a}}$ Omeprazole $50 \mu \mathrm{M}$ CYP1A2 (AhR), phenobarbital $750 \mu \mathrm{M}$ CYP2B6 (CAR), rifampicin $20 \mu \mathrm{M}$ CYP3A4 (PXR)

${ }^{\mathrm{b}}$ Human hepatocyte donor designation 

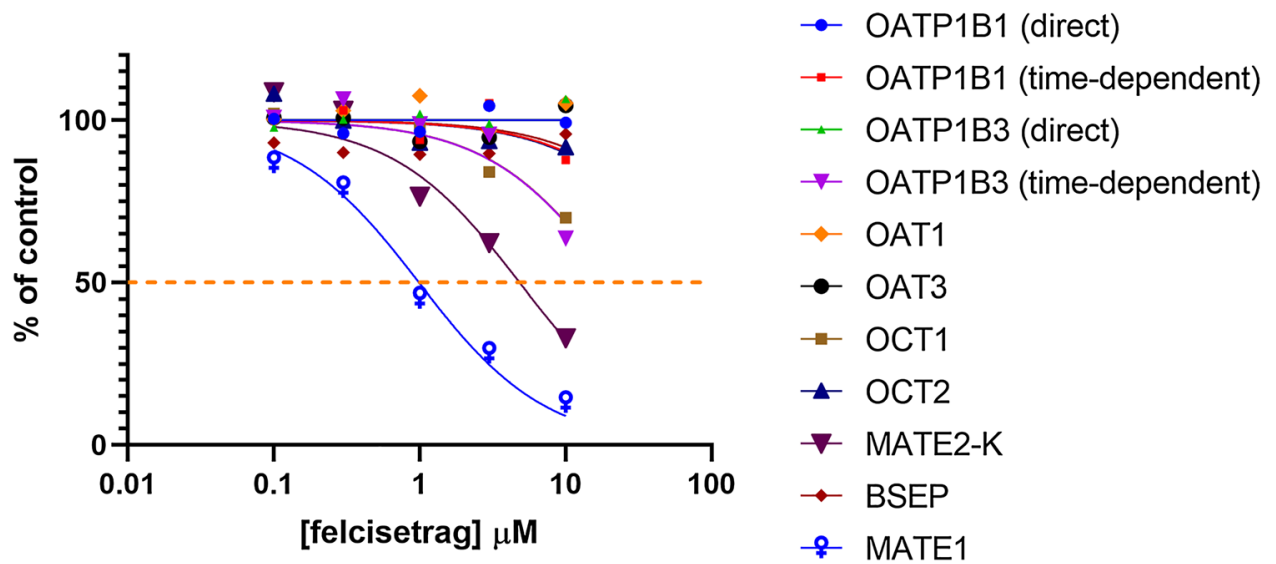

Fig. 6 Effect of felcisetrag on the uptake of transporter substrates. The orange line depicts $50 \%$ of the control activity remaining. Inhibition of OATP1B1 was evaluated without (blue circles) and with preincubation (red squares). Inhibition of OATP1B3 was evaluated without (green triangle) and with preincubation (purple inverted tri- angle). Inhibition of OAT1 (orange diamond), OAT3 (black circle), OCT1 (brown square), OCT2 (blue triangle), MATE2-K (dark purple inverted triangle), BSEP (maroon diamond) and MATE1 (blue female sign), was determined with no preincubation
Table 5 Coverage of human formed metabolites in nonclinical species

\begin{tabular}{|c|c|c|c|c|c|c|c|c|c|}
\hline \multirow[t]{3}{*}{ Designation } & \multicolumn{3}{|c|}{$\begin{array}{l}\text { Plasma: percent of total } \\
\text { plasma radioactivity (mean) }\end{array}$} & \multicolumn{6}{|c|}{ Excreta: percent of dose administered } \\
\hline & \multirow{2}{*}{$\begin{array}{l}\text { Human }^{\mathrm{a}} \\
0-168 \mathrm{~h}\end{array}$} & \multirow{2}{*}{$\begin{array}{l}\mathrm{Rat}^{\mathrm{b}} \\
0-4 \mathrm{~h}\end{array}$} & \multirow{2}{*}{$\begin{array}{l}\overline{\operatorname{Dog}^{c}} \\
0-4 h\end{array}$} & \multicolumn{2}{|c|}{ Human $^{\mathrm{a}}$} & \multicolumn{2}{|l|}{ Rat $^{b}$} & \multicolumn{2}{|l|}{$\operatorname{Dog}^{\mathrm{c}}$} \\
\hline & & & & UR & FE & UR & FE & UR & FE \\
\hline Total dose excreted & NA & NA & NA & 55.6 & 28.8 & 30.8 & 62.8 & 13.2 & 74.4 \\
\hline M1 & 1.35 & 0.6 & 0.4 & 2.55 & ND & 0.5 & 0.5 & 0.2 & 10.2 \\
\hline M3 & 2.18 & $\mathrm{Y}$ & $\mathrm{Y}$ & 4.03 & 7.44 & $\mathrm{Y}$ & $\mathrm{Y}$ & $\mathrm{Y}$ & $\mathrm{Y}$ \\
\hline M14 & $\operatorname{Tr}^{\mathrm{d}}$ & ND & $\mathrm{Y}$ & 3.62 & ND & ND & ND & $\mathrm{Y}$ & ND \\
\hline M4/M5 & 0.54 & 3.2 & 0.4 & 1.34 & 2.86 & 2.5 & 9.3 & 0.4 & 2.4 \\
\hline $\mathrm{M} 16^{\mathrm{e}}$ & ND & ND & ND & & & $\mathrm{Y}$ & $\mathrm{Y}$ & $\mathrm{Y}$ & $\mathrm{Y}$ \\
\hline M17 & 0.66 & ND & ND & 0.70 & 0.69 & ND & ND & $\mathrm{Y}$ & $\mathrm{Y}$ \\
\hline Unknown-1 & 4.42 & ND & ND & ND & ND & ND & ND & ND & ND \\
\hline M7 & ND & ND & ND & ND & 0.40 & ND & 6.1 & ND & ND \\
\hline M9 & 0.38 & Y & Y & 0.50 & ND & Y & ND & $\mathrm{Y}$ & ND \\
\hline Felcisetrag & 74.3 & 79.1 & 81.2 & 37.41 & 11.53 & 22.6 & 19.5 & 6.1 & 5.8 \\
\hline $\mathrm{M} 10^{\mathrm{f}}$ & $3.50^{\mathrm{f}}$ & 5.1 & 11.4 & 0.41 & 0.46 & 2.9 & 6.6 & 4.9 & 39.8 \\
\hline $\mathrm{M} 11^{\mathrm{f}}$ & & $\mathrm{Y}$ & $\mathrm{Y}$ & 0.21 & ND & $\mathrm{Y}$ & ND & $\mathrm{Y}$ & $\mathrm{Y}$ \\
\hline Others & ND & ND & ND & 4.83 & 5.42 & 2.3 & 20.8 & 1.6 & 16.2 \\
\hline
\end{tabular}

$H$ hour, $N A$ not applicable, $U R$ urine, $F E$ feces, $N D$ not detected in the corresponding matrix, $T r$ trace, $Y$ metabolites were identified in the corresponding rat and dog matrix by LC-MS

${ }^{a}$ Humans were administered $0.5 \mathrm{mg}$ dose intravenously

${ }^{b}$ Rats were administered $0.5 \mathrm{mg} / \mathrm{kg}$ dose intravenously

${ }^{c}$ Dogs were administered $0.5 \mathrm{mg} / \mathrm{kg}$ dose intravenously

${ }^{\mathrm{d}}$ Detected by liquid chromatography tandem mass spectrometry (LC-MS/MS) in 1-h human plasma

${ }^{\mathrm{e}}$ Metabolite M16 coelutes with M4 and M5 and were integrated as a single peak in human urine and feces

${ }^{\mathrm{f}}$ Metabolite M10 and M11 were integrated together as one peak in human plasma. 
oxidation, and oxidative $N$-dealkylation pathways or by a combination thereof. In plasma, all metabolites, including any unidentified ${ }^{14} \mathrm{C}$-radiolabeled peaks, were each detected at $<10 \%$ of the total plasma radioactivity and at $<25 \%$ of felcisetrag exposure. The minor metabolites observed in human circulation were not originally identified in the plasma samples from rat and dog, thus targeted reanalysis conducted as part of due diligence efforts subsequently confirmed exposure. Metabolite M3, resulting from oxidative $\mathrm{N}$-dealkylation of the central piperidinyl moiety, was the most abundant metabolite identified accounting for $13.6 \%$ of the total dose recovered in excreta. All individual unidentified metabolites in excreta were present at $<2 \%$ of the total dose administered. No phase II metabolites were detected. Since no major metabolites were identified, the evaluation of their potential to contribute to pharmacology, toxicity, or DDI is not warranted.

Reaction phenotyping demonstrated that oxidative metabolism of felcisetrag was almost exclusively mediated by CYP3A4. An important consideration for evaluating the risk for felcisetrag to be a victim of DDI is the extent of elimination through metabolism. While the metabolites formed in human were consistent with those generated in dog and rat, there were some differences in the contribution of metabolism to total clearance between human and nonclinical species. Specifically, the overall elimination fraction of felcisetrag in human was primarily renal at 0.443 , with metabolism accounting for 0.420 and biliary/luminal clearance accounting for 0.137 . In the case of felcisetrag, $98 \%$ of its metabolism is mediated by CYP3A; however, since the total clearance through metabolism is $42.0 \%$, the impact of strong inhibition of CYP3A metabolism on felcisetrag exposure is low (estimated to be $<1.7$-fold from $\left.\frac{1}{1-(0.420 \times 0.98)}\right)$ [16]. This is consistent with the weak inhibition observed when administered IV on top of oral itraconazole, AUC ratio $=1.5$.

\section{Conclusions}

In summary, the felcisetrag's DME properties in human and nonclinical species demonstrated similarity in the identity of metabolites formed. Use of the ultra-sensitive AMS technology led to the detection of additional, minor metabolites in the human samples, leading to reexamination of the animal samples and confirmation of their coverage. Further, in vitro studies determined that felcisetrag is not an inhibitor or inducer of CYP enzymes, thereby reducing the need to exclude concomitant medications due to DDI potential. Since no metabolites of felcisetrag were considered to be major, there no additional studies are needed to characterize
DDI potential. These findings add to the body of data on felcisetrag, further establishing its DME properties.

Supplementary Information The online version contains supplementary material available at https://doi.org/10.1007/s13318-021-00751-8.

Acknowledgements The authors thank scientists at Axcelead, Jayaprakasam Bolleddula and Maria Rosario.

\section{Declarations}

Funding This study was sponsored by Takeda Development Center Americas, Ltd.

Conflict of interest SP, SKC, RC, XZ, SKB, YL, and DR are/were employees of Takeda Development Center Americas, Inc., when this work was conducted, and received stock or stock options.

Ethics approval All nonclinical studies conformed with the "Guideline for Non-clinical Pharmacokinetic Studies (Notification of the Pharmaceutical and Medical Safety Bureau, Ministry of Health and Welfare No. 496 as of June 26, 1998)" and the Data Integrity Standards for Product Application, Article 43 of the Enforcement Regulations of the Act on Securing Quality, Efficacy and Safety of Pharmaceuticals, Medical Devices, Regenerative and Cellular Therapy Products, Gene Therapy Products and Cosmetics (Ordinance of the Ministry of Health and Welfare No. 1 as of February 1, 1961) and were approved by the Institutions Animal Care and Use Committee.

Consent to participate All volunteers provided written informed consent.

Consent to publish Not applicable.

Availability of data and material All data and analysis generated during these studies are included in this article (and its supplementary information) or are available upon request to the corresponding author. All figures were prepared using GraphPad Prism v.8.0 (San Diego, CA).

Code availability There was no code used in the analysis contained within this article.

Author contributions Participated in research design: SP, SKC, RC, XZ, SKB, YL. Conducted experiments: SKB, SP, XZ. Performed data analysis: DR, SKB, SKC, SP, XZ. Wrote or contributed to the writing of the manuscript: SP, SKC, XZ, SKB, DR.

Open Access This article is licensed under a Creative Commons Attribution-NonCommercial 4.0 International License, which permits any non-commercial use, sharing, adaptation, distribution and reproduction in any medium or format, as long as you give appropriate credit to the original author(s) and the source, provide a link to the Creative Commons licence, and indicate if changes were made. The images or other third party material in this article are included in the article's Creative Commons licence, unless indicated otherwise in a credit line to the material. If material is not included in the article's Creative Commons licence and your intended use is not permitted by statutory regulation or exceeds the permitted use, you will need to obtain permission directly from the copyright holder. To view a copy of this licence, visit http://creativecommons.org/licenses/by-nc/4.0/. 


\section{References}

1. Venara A, Neunlist M, Slim K, Barbieux J, Colas PA, Hamy A, et al. Postoperative ileus: pathophysiology, incidence, and prevention. J Visc Surg. 2016;153(6):439-46.

2. Colorectal Writing Group for the S-CC, Ehlers AP, Simianu VV, Bastawrous AL, Billingham RP, Davidson GH, et al. Alvimopan use, outcomes, and costs: a report from the surgical care and outcomes assessment program comparative effectiveness research translation network collaborative. J Am Coll Surg. 2016;222(5):870-7.

3. The FO, Bennink RJ, Ankum WM, Buist MR, Busch OR, Gouma DJ, et al. Intestinal handling-induced mast cell activation and inflammation in human postoperative ileus. Gut. 2008;57(1):33-40.

4. Stakenborg N, Labeeuw E, Gomez-Pinilla PJ, De Schepper S, Aerts R, Goverse G, et al. Preoperative administration of the 5-HT4 receptor agonist prucalopride reduces intestinal inflammation and shortens postoperative ileus via cholinergic enteric neurons. Gut. 2019;68(8):1406-16.

5. Sloots CE, Rykx A, Cools M, Kerstens R, De Pauw M. Efficacy and safety of prucalopride in patients with chronic noncancer pain suffering from opioid-induced constipation. Dig Dis Sci. 2010;55(10):2912-21.

6. Beattie DT, Armstrong SR, Vickery RG, Tsuruda PR, Campbell CB, Richardson C, et al. The Pharmacology of TD-8954, a potent and selective 5-HT(4) receptor agonist with gastrointestinal prokinetic properties. Front Pharmacol. 2011;2:25.

7. McKinnell RM, Armstrong SR, Beattie DT, Fatheree PR, Long DD, Marquess DG, et al. Discovery of TD-8954, a clinical stage
5-HT(4) receptor agonist with gastrointestinal prokinetic properties. Bioorg Med Chem Lett. 2013;23(14):4210-5.

8. Czerniak R, Chen Y, Aldairy W, Barnes C, Bourdet D, Almansa $\mathrm{C}$, Chen C. Evaluation of the safety, tolerability, pharmacokinetic and pharmacodynamic profiles of TAK-954 in a randomized, placebo-controlled phase 1 study. AGA Gastroenterol. 2019.

9. Hamilton RA, Garnett WR, Kline BJ. Determination of mean valproic acid serum level by assay of a single pooled sample. Clin Pharmacol Ther. 1981;29(3):408-13.

10. Nishihara M, Ramsden D, Balani SK. Evaluation of the drug-drug interaction potential for trazpiroben (TAK-906), a D2/D3 receptor antagonist for gastroparesis, towards cytochrome P450s and transporters. Xenobiotica. 2021;51(6):668-79.

11. Achour B, Barber J, Rostami-Hodjegan A. Expression of hepatic drug-metabolizing cytochrome p450 enzymes and their intercorrelations: a meta-analysis. Drug Metab Dispos. 2014;42(8):1349-56.

12. Roffey SJ, Obach RS, Gedge JI, Smith DA. What is the objective of the mass balance study? A retrospective analysis of data in animal and human excretion studies employing radiolabeled drugs. Drug Metab Rev. 2007;39(1):17-43.

13. EMA. Guideline on the investigation of drug interactions. 2012.

14. FDA. In vitro drug interaction studies - cytochrome p450 enzymeand transporter-mediated drug interaction guidance for industry. 2020.

15. PMDA. Pharmaceuticals and Medical Devices Agency (Japan): drug interaction guideline for drug development and labelling recommendations. 2018.

16. Rowland M, Matin SB. Kinetics of drug-drug interactions. J Pharmacokinet Biopharm. 1973;1(6):553-67. 